\title{
Quercetin quantification in a Jeju Dendropanax morbifera Lev. extract by varying different parts, harvest times, and extraction solvents
}

\author{
Ki Hoon Lee ${ }^{1}$, Hye Jin $\mathrm{Na}^{2}$, Chang Khil Song ${ }^{3}$, So Young Kang ${ }^{3}$, Sunoh Kim ${ }^{1 *}$ \\ ${ }^{1}$ B\&Tech Co., Ltd., R\&D Center, Gwangju 61239, Korea \\ ${ }^{2}$ Korea Food Information Institute, DaeJeon 34068, Korea \\ ${ }^{3}$ Agency for Jeju Plant Resources Dendropanax, Jeju 63243, Korea
}

\section{제주 황칠나무의 활용성 제고를 위한 부위별, 수확시기별, 추출용매별 quercetin 함량 분석}

\author{
이기훈 ${ }^{1} \cdot$ 나혜진 $^{2} \cdot$ 송창길 $^{3} \cdot$ 강소영 $^{3} \cdot$ 김선오 ${ }^{*}$ \\ ${ }^{1}\left(\right.$ 주)비엔텍 중앙연구원, ${ }^{2}$ (주)한국식품정보원 식품안전연구소, ${ }^{3}$ (사)제주자원식물황칠사업단
}

\begin{abstract}
Dendropanax morbifera Leveille (Araliaceae) is an endemic species growing in the south-westem part of South Korea that has been used in folk medicine and health functional food. In this study, we investigated an extract of quercetin in Jeju D. morbifera by varying different parts (fruit, sprouts, leaves, sprigs, and branches), harvest times, and extraction solvents. In addition, we aimed to establish a simple and reliable HPLC/UV analytical method to determination of quercetin for the quality control and base line data of the Jeju $D$. morbifera extract as a health functional food ingredient. The analytical specificity was determined with retention time and photo diode array (PDA) spectrum by analyzing quercetin using HPLC and comparing the results to those of extracts. This analytical method for quercetin was validated for its limit of detection (LOD), limit of quantitation (LOQ), precision, and accuracy. A high linearity in the standard calibration curve was obtained, with a coefficient of determination $\left(\mathbf{R}^{2}\right)$ of 0.9996. Also, the LOD and LOQ values were found to be $0.28 \mu \mathrm{g} / \mathrm{mL}$ and $0.85 \mu \mathrm{g} / \mathrm{mL}$, respectively, and the recoveries of quantified compounds ranged from $97.91 \%$ to $104.10 \%$. Furthermore, the relative standard deviation (RSD) values of data from the intra- and inter-day precision analyses were less than $1.36 \%$ and $3.65 \%$, respectively. As a result, the highest quercetin content among the extracts of Jeju $D$. morbifera leaves was found to be 20.14 $\mathrm{mg} / \mathrm{g}$, which was extracted at harvest in May (cultivation period 10 years) with $60 \% \mathrm{EtOH}$. All in all, we believe that the results obtained would be helpful in the development of nutraceutics and natural medicines and for the quality control of $D$. morbifera.
\end{abstract}

Key words : Dendropanax morbifera Lev., quercetin, HPLC, analysis, validation

\section{서 론 \\ 국민생활 수준의 향상, 핵가족화, 여성의 사회참여가 높}

*Corresponding author. E-mail : sunoh@korea.ac.kr

Phone : 82-62-528-2201, Fax : 82-62-528-2202

Received 22 February 2018; Revised 15 May 2018; Accepted 5 June 2018.

Copyright (c) The Korean Society of Food Preservation. All rights reserved.
아짐에 따라 보다 영양적이고 간편한 서구식 식생활을 추구 하면서 점차 다양화, 고급화 및 편의화 방향으로 바뀌어 가고 있다. 따라서 기아와 영양부족으로 인한 건강관리의 문제 보다는 과잉섭취로 인한 성인병이 문제되고 있으며 각종 성인병의 치료가 약물이나 의료적 치료보다는 식생활 의 조절, 건강기능식품 섭취 등에 의한 질병예방 차원에 더욱 관심을 가지게 되었다(1). 특히 천연 약용 및 식용 식물은 다양한 질병의 예방과 치료를 위해 사용되어 왔으 며, 안전성이 확보된 천연물자원들로 널리 사용되고 있다 
(2).

건강기능식품을 개발하고 생산하기 위해서는 원료의 표 준화와 규격화가 필수적으로 선행되어야 한다. 원재료의 기능성과 표준화관리를 위해 가장 일반적으로 사용하는 방법은 지표성분의 표준화 방법이며, 지표성분은 특이성, 대표성, 안정성, 용이성 등을 고려하여야 한다. 또한 지표성 분을 확인하는 방법은 공인된 방법이나 정밀하다고 판단되 는 분석방법을 사용하며 과학적인 타당성과 신뢰성이 검증 되어야 한다(3).

황칠나무(Dendropanax morbifera Leveille)는 두릅나무 과에 속하는 상록 활엽수로 우리나라 제주도, 완도, 해남, 보길도 등 서남해안 지역 및 일부 온대지역에서 자생하는 수종이다(4). 학명에서 뜻하는 바와 같이 목본(Dendro), 전 능약(全能藥: panax)이라는 의미가 있으며, 수피에 상처를 내면 황색의 유액이 흘러나오는데, 예로부터 고급 도료로 사용되었다. 황칠나무는 $15 \mathrm{~m}$ 정도 자라고 줄기는 흑갈색 띄며 작은 가지는 녹색을 띈다. 잎은 호생하고 달걀모양 혹은 타원형으로 어린가지의 잎은 3-5갈래로 갈라져 있으 나 성장하면 심장형으로 변한다. 꽃은 6월경 개화되며 열매 는 타원형 핵과로 10 월경 검은색으로 여물게 된다(5). 황칠 수액의 주요 성분은 정유성분으로서 sesquiterpene인 $\beta$ -selinene, $\beta$-cubebene, $\beta$-elemene, germacrene $\mathrm{D}, \gamma$-cadinene 등이 보고되었으며 $(4,6,7)$, 최근에는 황칠나무 잎으로부터 rutin, chlorogenic acid, (+)-catechin, ferulic acid, myricetin, quercetin, resveratrol 등의 페놀성 화합물들이 포함되어 있 다고 보고(8)되고 있지만, 황칠나무를 특징지을 수 있는 지표성분으로 활용할 수 있는 신규 성분들이 보고된 연구는 매우 미미한 실정이다. 황칠나무에 포함된 이러한 flavonoid 및 polyacetylene 화합물은 항산화, 항암, 항당뇨, 항동맥경 화, 항염 등의 다양한 연구가 보고(9-11)되었으며, 황칠나무 의 생리활성 기능과 관련된 연구들이 최근까지도 활발히 진행되고 있다. 특히 quercetin은 벤젠고리의 탄소에 - $\mathrm{OH}$ 기 와 탄소의 2 와 3 사이의 이중결합, 4 의 탄소에 carbonyl기, 그리고 $\mathrm{A}$ 고리와 $\mathrm{B}$ 고리에 결합되어 있는 $-\mathrm{OH}$ 기에 의해서 활성산소의 산화활동을 억제하거나 제거하는 항산화 활성 능력이 매우 좋은 물질로 알려져 있다(12). 그러나 지금까지 황칠나무의 지표성분을 설정하는 연구는 전무한 실정이며, 특히 황칠나무는 잎, 줄기, 뿌리 등 다양한 부위를 식품으로 사용가능한 원료이므로 각 부위별, 그리고 년생별, 수확 시기별 성분의 함량변화에 대한 연구가 필요한 실정이다. 이에 본 연구자들은 문헌을 통해 보고된 황칠나무의 성분들 을 대상으로 제주황칠나무 추출물에서의 성분을 스크리닝 하였으나 대부분의 성분들이 불검출 되거나 검출한계 이하 의 함량으로 분석이 되었다. 그 중 성분 검출이 뚜렷하고 다양한 생리활성 기능을 갖는 quercetin을 본 연구의 지표성 분으로 설정 가능성을 판단하기 위해 quercetin을 분석 대상 물질로 선정하고 분석법 검증 과정을 통해 분석결과의 신뢰
도를 확보하고 제주 황칠나무의 부위별, 수확시기별, 추출 용매별 quercetin의 함량 차이를 비교 분석하여 황칠나무 추출물의 품질관리 지표 및 기초자료로써의 활용성을 제시 하고자 한다.

\section{재료 및 방법}

\section{황칠나무 추출물 제조}

본 실험에서 사용한 황칠나무 추출물은 다음 추출조건에 의해 추출, 동결건조 분말화한 것을 한국식품정보원 (Daejeon, Korea)으로부터 분양 받아 사용하였다. 제주시 및 서귀포시에서 채취한 황칠나무는 5 년생, 8 년생, 10 년생, 및 15 년생으로 수령을 구분하고, 채취 시기는 5 월, 8 월 및 11 월로 나누었으며, 채취 부위는 열매, 새싹, 성숙잎, 잔가 지, 줄기로 구분하였다. 각 시료는 $2 \mathrm{~cm}$ 내외로 세절한 후 $50^{\circ} \mathrm{C}$ 에서 15 시간 열풍건조를 실시하고 각 시료에 10 배수의 추출용매로 열수 $\left(80^{\circ} \mathrm{C}, 3 \mathrm{~h}\right), 30 \%$ 주정 $\left(75^{\circ} \mathrm{C}, 4 \mathrm{~h}\right)$ 및 $60 \%$ 주정 $\left(70^{\circ} \mathrm{C}, 4 \mathrm{~h}\right)$ 으로 추출하였다.

\section{표준용액의 조제}

표준품으로서 quercetin(Sigma Chemical Co., St. Louis, $\mathrm{MO}, \mathrm{USA})$ 을 $\mathrm{MeOH}$ 로 용해시킨 후 $1,000 \mathrm{\mu g} / \mathrm{mL}$ 의 농도가 되도록 표준원액으로 제조하였다. 이를 $50 \% \mathrm{MeOH}$ 로 희석 하여 $5,10,25,50$, 및 $100 \mu \mathrm{gg} / \mathrm{mL}$ 농도가 되도록 제조한 후 $0.45 \mu \mathrm{m}$ PVDF membrane filter(Millipore, Milford, MA, USA)로 여과한 뒤 표준용액으로 사용하였다. 표준용액의 크로마토그램에서 얻은 피크의 농도별 면적을 이용하여 작성한 표준검량선으로부터 quercetin 함량을 구하였다.

\section{시험용액의 조제}

황칠나무 추출물의 quercetin 분석은 시료를 산 가수분해 처리하여 분석하였으며, Crozier 등(13)의 방법을 변형하여 실시하였다. 시료 분말 $0.1 \mathrm{~g}$ 을 정밀히 취하여 $5 \% \mathrm{H}_{2} \mathrm{SO}_{4}$ 이 포함된 $50 \% \mathrm{MeOH} 3 \mathrm{~mL}$ 를 가하고 $90^{\circ} \mathrm{C}$ 에서 30 분간 산가수 분해를 실시하였다. 가수분해가 종료된 용액을 $25 \mathrm{~mL}$ 정용 플라스크에 $50 \% \mathrm{MeOH}$ 로 정용한 뒤 $0.45 \mu \mathrm{m}$ syringe filter(Whatman Co., Morris, NJ, USA)로 여과한 용액을 시험 용액으로 사용하였다.

\section{HPLC분석}

황칠나무 추출물의 quercetin 분석은 Table 1 에 요약되어 있다. HPLC 장비는 1525 Binary pump, column oven 및 2998 photodiode array detector(Waters HPLC system, Millford, MA, USA)를 사용하였고, 데이터 수집 및 처리를 위해 Empower3 software program(Waters Corporation, Milford, MA, USA)을 사용하여 피크면적을 구하였다. 분석 
용 컬럼은 PhenoSphere ${ }^{\mathrm{TM}} \mathrm{ODS}(2)$ column $(4.6 \times 250 \mathrm{~mm}, 5$ $\mu \mathrm{m}$, Phenomenex, Torrance, CA, USA)을 사용하였으며, 이 동상으로는 trifluoroacetic acid(TFA, Sigma Chemical Co., St. Louis, MO, USA)가 함유된 용매로 용매 $\mathrm{A}(0.1 \%$ TFA 함유 water), 용매 $\mathrm{B}(0.1 \%$ TFA 함유 acetonitrile)를 사용하였 고, $1.0 \mathrm{~mL} / \mathrm{min}$ 의 유속으로 분석을 실시하였다. UV는 370 $\mathrm{nm}$ 파장에서 측정하였고, 시료 주입량은 $20 \mu \mathrm{L}$ 를 사용하였 다.

Table 1. Analytical condition of HPLC for analysis of quercetin

\begin{tabular}{|c|c|c|c|}
\hline Parameters & \multicolumn{3}{|c|}{ Condition } \\
\hline HPLC model & \multicolumn{3}{|c|}{ Waters 1500 -series } \\
\hline Column & \multicolumn{3}{|c|}{ PhenoSphere $^{\mathrm{TM}}$ ODS(2) column $(4.6 \times 250 \mathrm{~mm}, 5 \mu \mathrm{m})$} \\
\hline Detector & \multicolumn{3}{|c|}{ UV $370 \mathrm{~nm}$} \\
\hline Flow rate & \multicolumn{3}{|c|}{$1.0 \mathrm{~mL} / \mathrm{min}$} \\
\hline Column temperature & \multicolumn{3}{|c|}{$40^{\circ} \mathrm{C}$} \\
\hline Injection volume & \multicolumn{3}{|c|}{$20 \mu \mathrm{L}$} \\
\hline \multirow{5}{*}{ Gradient } & Time (min) & $\% \mathrm{~A}^{1)}$ & $\% \mathrm{~B}^{2)}$ \\
\hline & 2 & 80 & 20 \\
\hline & 25 & 55 & 45 \\
\hline & 30 & 0 & 100 \\
\hline & 31 & 80 & 20 \\
\hline
\end{tabular}

${ }^{10} 0.1 \%$ trifluoroacetic acid in water.

${ }^{2)} 0.1 \%$ trifluoroacetic acid in acetonitrile.

\section{분석법의 유효성 검증}

지표성분의 HPLC 분석법 검증은 의약품 등 시험방법 밸리데이션에 대한 가이드라인 $(14,15)$ 을 근거하여 특이성 (specificity), 직선성(linearity), 정확성(accuracy), 정밀성 (precision)등을 수행하였으며, 직선성 검증으로부터 얻어 진 검량선의 기울기와 표준편차를 이용해 검출한계(LOD) 및 정량한계 $(\mathrm{LOQ})$ 를 확인하였다. 유효성 검증은 하나의 균질화된 시료(10년생, 5 월 채취한 황칠나무 잎의 $60 \%$ 주 정추출물)로 실시하였다.

특이성(specificity) 검증은 quercetin 표준용액과 전처리 한 시료용액을 HPLC로 분석한 후 크로마토그램을 비교하 여 quercetin peak의 분리도 및 머무름 시간을 확인하였으며 photo diode array(PDA) spectrum을 측정하여 동일한 spectrum을 나타내는지 확인하였다.

직선성, 검출한계 및 정량한계(linearity, $\mathrm{LOD}$ and $\mathrm{LOQ}$ ) 는 단계적으로 희석한 quercetin 표준용액을 HPLC로 분석 하여 3회 반복 측정하였으며 peak 면적비에 대한 농도비의 관계를 나타내는 표준검량선을 작성하였다. 검출한계와 정 량한계는 표준용액의 크로마토그램을 이용하여 얻어진 검 량선의 기울기와 표준편차에 근거하여 계산하였다.
$\mathrm{LOD}=3.3 \times$ standard deviation of the response/slope of the calibration curve

$\mathrm{LOQ}=10 \times$ standard deviation of the response/slope of the calibration curve

정확성(accuracy)을 확인하기 위해 표준용액 10,25 , 및 $50 \mathrm{\mu g} / \mathrm{mL}$ 를 시료에 첨가하여 회수율을 구하였다. 각 시험 은 3회 반복 $\mathrm{HPLC}$ 로 분석하여 결과값이 참값에 근접한지 분석에 의해 회수되는 양을 백분률로 환산하였다.

정밀성(precision)을 확인하기 위해 전처리법에 따라 처 리된 시험용액을 일내분석(intra-day)과 일간분석(inter-day) 으로 나누어 진행하였다. Intra-day는 1일 3구간 6시간마다 (9:00 AM, 3:00 PM, 9:00 PM)진행하였으며 각 3회씩 반복 하여 HPLC로 분석하였고, inter-day는 1 일 1 구간으로 3 일간 진행하였다. 각 시험은 구간마다 3회 반복하여 분석하여 정밀성를 나타내는 상대표준편차(relative standard deviation, $\mathrm{RSD})$ 를 구하였다.

\section{다양한 조건별 황칠나무 추출물의 quercetin 정량분석}

한국식품정보원으로부터 분양받은 황칠나무 추출물은 전처리법에 따라 처리 후 $0.45 \mu \mathrm{m}$ syringe filter로 여과하여 시험용액으로 사용하였다. 각 시료는 3회 반복하여 HPLC 로 분석하였으며, 표준용액의 피크 면적을 통해 작성된 표 준검량선을 이용하여 시험용액의 quercetin 농도를 산출하 였다.

\section{결과 및 고찰}

\section{특이성 확인}

특이성 시험을 통해 quercetin 표준용액과 시험용액의 크로마토그램을 비교하여 다른 물질과의 간섭 없이 표준물 질의 peak가 분리되는지 확인하였다. 표준용액과 황칠나무 추출물을 비교한 결과, 약 11 분대에서 quercetin peak가 동 일하게 검출됨을 확인하였고, 시험용액에서 다른 peak와 간섭 없이 완전히 분리됨을 확인할 수 있었다. 또한 표준용 액과 시료용액의 PDA spectrum도 동일한 패턴을 나타내어 본 시험법의 특이성을 확인할 수 있었다(Fig. 1).

\section{직선성, 검출한계 및 정량한계}

표준품 quercetin을 $5,10,25,50$, 및 $100 \mathrm{\mu g} / \mathrm{mL}$ 의 농도로 단계적으로 희석한 뒤 HPLC로 분석하여 표준검량선을 작 성하였다. 검량선의 결정계수 $\left(\mathrm{R}^{2}\right)$ 는 0.9996 으로 높은 직선 성을 보였으며, 검출한계는 $0.28 \mu \mathrm{g} / \mathrm{mL}$, 정량한계는 0.85 $\mathrm{\mu g} / \mathrm{mL}$ 이었다. 이 결과는 시료에 적용할 경우 검출한계는 $0.28 \mu \mathrm{g} / \mathrm{mL}$ 수준으로 검출이 가능하고, 정량한계는 0.85 $\mu \mathrm{g} / \mathrm{mL}$ 수준까지 정량할 수 있는 최저 농도를 의미한다. 


\section{정확성 및 회수율}

지표성분을 농도별 시험용액으로 조제하여 HPLC 분석 에 의해 회수되는 양을 확인하였다. Table 2에 나타난 바와 같이 quercetin의 회수율은 $10 \mathrm{\mu g} / \mathrm{mL}$ 의 농도에서는 $104.10 \%, 25 \mu \mathrm{g} / \mathrm{mL}$ 농도에서는 $97.91 \%, 50 \mu \mathrm{g} / \mathrm{mL}$ 농도에서 는 $98.37 \%$ 범위의 회수율을 보였다. $\mathrm{Hu}$ 등(16)은 quercetin 분석방법 검증에서 97.1-105.4\%의 회수율을 보였으며, Wang과 Helliwell(17)은 녹차, 홍차잎, 녹차물에서의
Table 2. Intra- and inter-day precision and accuracy data of the HPLC method for the determination of quercetin in Jeju Dendropanax morbifera Lev. extracts

\begin{tabular}{cccc}
\hline $\begin{array}{c}\text { Spiked amount } \\
(\mu \mathrm{g} / \mathrm{mL})\end{array}$ & $\begin{array}{c}\text { Intra-day } \\
(\mathrm{CV} \%)\end{array}$ & $\begin{array}{c}\text { Inter-day } \\
(\mathrm{CV} \%)\end{array}$ & $\begin{array}{c}\text { Recovery } \\
(\%)\end{array}$ \\
\hline 10 & 2.98 & 3.65 & $104.10 \pm 1.50$ \\
25 & 1.97 & 2.25 & $97.91 \pm 0.89$ \\
50 & 1.36 & 2.11 & $98.37 \pm 1.37$ \\
\hline
\end{tabular}
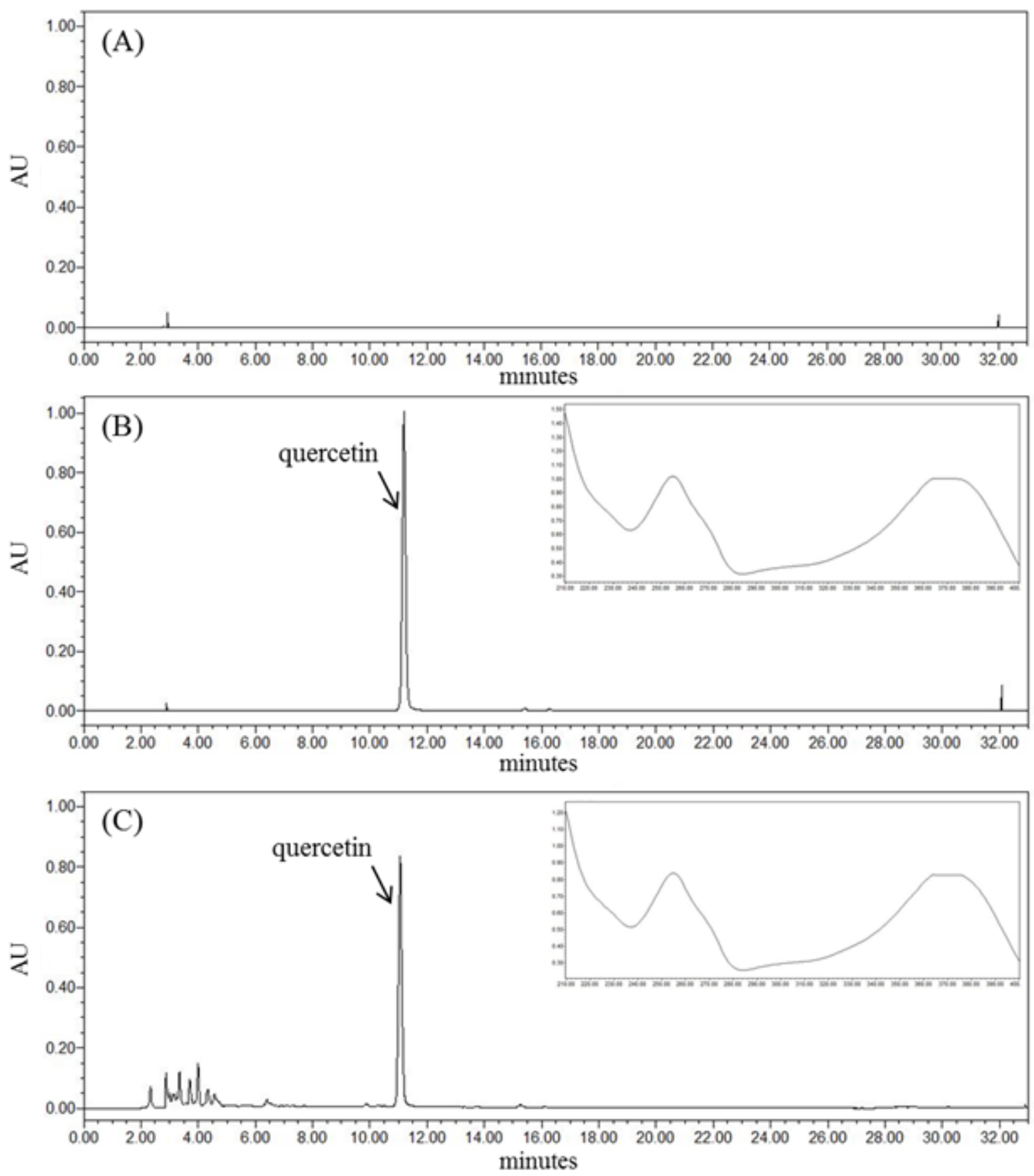

Fig. 1. HPLC chromatogram and PDA spectrum of (A) Blank, (B) quercetin standard and (C) Jeju Dendropanax morbifera Lev. extract at $370 \mathrm{~nm}$ by a photodiode array detector. 
quercetin 분석을 통해 $102 \%$ 의 회수율을 얻어 본 연구결과 와 유사한 결과를 나타내어 본 시험법의 정확성을 확인할 수 있었다.

\section{정밀성 검토}

분석오차를 의미하는 정밀성은 균일한 하나의 시료로부 터 여러번 반복 채취하여 정해진 조건에 따라 측정하였을 때 각각의 측정값들 사이의 근접성을 의미하며, Table 2 와 같이 intra-day와 inter-day로 나누어 상대표준편차(RSD)를 측정하였다. Intra-day 분석에서의 정밀도는 $1.36-2.98 \%$ 이 었으며, inter-day분석에서의 정밀도는 2.11-3.65\%이었다. 이상의 분석결과, 황칠나무 추출물의 조건별 quercetin 함량 분석의 유효성을 검증하였다.

\section{다양한 조건별 황칠나무 추출물의 quercetin 함량분석}

본 연구에서는 제주산 황칠나무를 부위, 수확시기 및 추 출용매별로 나누어진 시료에 대하여 표준화한 분석법으로 quercetin 함량을 비교 분석하여 Table 3과 같이 나타내었다. 열매를 제외한 quercertin 함량은 0.31-20.14 mg/g의 범위로 함량 차이가 많이 났으며, 가지 부위보다는 잎 부위에서 높은 함량으로 나타났다. 각 시료들의 함량차이는 각각 부 위별로 나누어서 각 부위에서 가장 낮게 측정된 함량값을 기준으로 통계 분석을 실시하여 표시하였다. 각 부위별로 채취 시기별, 년생별, 추출방법별 심층 분석을 실시한 결과, 새싹 부위는 10 년생을 제외하고 8 년생과 15 년생을 5 월에 채취한 새싹 부위 추출물이 유의적으로 높은 함량을 보였다 ( $<<0.001)$. 성숙잎 부위를 추출용매별로 함량차이를 비교한 결과 열수추출물보다 주정 함량이 높아질수록 quercetin 함 량이 증가되는 것을 볼 수 있었으며, 특히 5 월에 채취한 10 년생 성숙잎의 경우 열수 추출물이 $5.89 \mathrm{mg} / \mathrm{g}, 30 \%$ 주정 추출물이 $18.06 \mathrm{mg} / \mathrm{g}, 60 \%$ 주정 추출물이 $20.14 \mathrm{mg} / \mathrm{g}$ 으로 주정 함량이 높아지는 추출방법일수록 quercetin함량이 유 의적으로 증가되는 것을 볼 수 있었다( $\mathrm{p}<0.001)$. 성숙잎 부위를 계절별로 함량차이를 비교한 결과 10 년생과 15 년생 성숙잎의 모든 추출물에서 5 월에 채취한 성숙잎의 quercetin 함량이 높은 것을 볼 수 있었으나, 8 년생의 경우에는 11 월에 채취한 추출물이 미약하게 quercetin함량이 증가하는 것을 볼 수 있었다. 성숙잎을 년생별로 함량차리를 비교한 결과 5 월을 기준으로 비교하면 8년생은 비교적 낮은 quercetin함 량을 보였으나, 10 년생 열수 추출물을 제외하고 10 년생과 15 년생의 모든 추출물은 서로 비슷한 수준의 높은 quercetin 함량을 볼 수 있었다.

잔가지 부위는 다른 부위에 비해 상대적으로 낮은 수준 의 quercetin 함량을 보이고 있어 잔가지 부위에서의 함량 비교는 큰 의미가 없는 수준의 함량이나, 그 중에서 8 년생의 11 월에 채취한 추출물이 다소 높은 quercetin 함량을 볼 수 있었다(p<0.05), 줄기 부위 또한 다른 부위에 비해 상대
Table 3. The quercetin contents of Jeju Dendropanax morbifera Lev. extracts

\begin{tabular}{|c|c|c|c|c|c|}
\hline Sample & $\begin{array}{l}\text { Parts } \\
\text { used }\end{array}$ & $\begin{array}{l}\text { Harvest } \\
\text { time }\end{array}$ & $\begin{array}{l}\text { Cultivation } \\
\text { period (year) }\end{array}$ & $\begin{array}{c}\text { Different } \\
\text { solvents ext. }\end{array}$ & $\begin{array}{c}\text { quercetin }^{1)} \\
(\mathrm{mg} / \mathrm{g})\end{array}$ \\
\hline 1 & \multirow{2}{*}{ fruit } & Sept. & 10 & water & - \\
\hline 2 & & Nov. & 10 & water & - \\
\hline 3 & \multirow{6}{*}{ Sprout } & May & 8 & water & $16.32 \pm 0.81^{* * *}$ \\
\hline 4 & & May & 10 & water & $10.22 \pm 0.67^{* * *}$ \\
\hline 5 & & May & 15 & water & $17.20 \pm 0.04^{* * *}$ \\
\hline 6 & & Nov. & 8 & water & $4.26 \pm 0.99^{* * \star}$ \\
\hline 7 & & Nov. & 10 & water & $9.74 \pm 0.19^{* * *}$ \\
\hline 8 & & Nov. & 15 & water & $1.41 \pm 0.10$ \\
\hline 9 & \multirow{16}{*}{ Leaf } & May & 8 & water & $5.40 \pm 0.13^{* * *}$ \\
\hline 10 & & May & 8 & $30 \% \mathrm{EtOH}$ & $7.22 \pm .0 .22^{* * *}$ \\
\hline 11 & & May & 10 & water & $5.89 \pm 0.10^{* * *}$ \\
\hline 12 & & May & 10 & $30 \% \mathrm{EtOH}$ & $18.06 \pm 1.81^{* * *}$ \\
\hline 13 & & May & 10 & $60 \% \mathrm{EtOH}$ & $20.14 \pm 0.19^{* * *}$ \\
\hline 14 & & May & 15 & water & $19.51 \pm 2.30^{* * *}$ \\
\hline 15 & & May & 15 & $30 \% \mathrm{EtOH}$ & $19.75 \pm 0.38^{* * *}$ \\
\hline 16 & & Aug. & 10 & water & $10.52 \pm 0.32^{* * *}$ \\
\hline 17 & & Aug. & 10 & $30 \% \mathrm{EtOH}$ & $12.62 \pm 0.44^{* * *}$ \\
\hline 18 & & Nov. & 8 & water & $8.70 \pm 0.11^{* * *}$ \\
\hline 19 & & Nov. & 8 & $30 \% \mathrm{EtOH}$ & $13.05 \pm 0.97^{* * *}$ \\
\hline 20 & & Nov. & 10 & water & $0.85 \pm 0.27$ \\
\hline 21 & & Nov. & 10 & $30 \% \mathrm{EtOH}$ & $6.61 \pm 1.04^{* * *}$ \\
\hline 22 & & Nov. & 10 & $60 \% \mathrm{EtOH}$ & $9.99 \pm 0.20^{* * *}$ \\
\hline 23 & & Nov. & 15 & water & $2.27 \pm 1.28$ \\
\hline 24 & & Nov. & 15 & $30 \% \mathrm{EtOH}$ & $8.05 \pm 1.11^{* * *}$ \\
\hline 25 & \multirow{6}{*}{ sprig } & May & 8 & water & $0.45 \pm 0.00^{* *}$ \\
\hline 26 & & May & 10 & water & $0.33 \pm 0.01$ \\
\hline 27 & & May & 15 & water & $0.36 \pm 0.01$ \\
\hline 28 & & Nov. & 8 & water & $0.81 \pm 0.05^{* * *}$ \\
\hline 29 & & Nov. & 10 & water & $0.47 \pm 0.03^{* *}$ \\
\hline 30 & & Nov. & 15 & water & $0.53 \pm 0.05^{* * *}$ \\
\hline 31 & \multirow{16}{*}{ branch } & May & 8 & water & $0.45 \pm 0.00$ \\
\hline 32 & & May & 8 & $30 \% \mathrm{EtOH}$ & $0.37 \pm 0.00$ \\
\hline 33 & & May & 10 & water & $0.61 \pm 0.00^{* *}$ \\
\hline 34 & & May & 10 & $30 \% \mathrm{EtOH}$ & $0.55 \pm 0.01^{*}$ \\
\hline 35 & & May & 10 & $60 \% \mathrm{EtOH}$ & $0.98 \pm 0.32^{* * *}$ \\
\hline 36 & & May & 15 & water & $0.59 \pm 0.02^{* *}$ \\
\hline 37 & & May & 15 & $30 \% \mathrm{EtOH}$ & $1.03 \pm 0.03^{* * *}$ \\
\hline 38 & & Aug. & 10 & water & $0.38 \pm 0.01$ \\
\hline 39 & & Aug. & 10 & $30 \% \mathrm{EtOH}$ & $0.31 \pm 0.00$ \\
\hline 40 & & Nov. & 8 & water & $0.74 \pm 0.07^{* \star *}$ \\
\hline 41 & & Nov. & 8 & $30 \% \mathrm{EtOH}$ & $1.16 \pm 0.09^{* * *}$ \\
\hline 42 & & Nov. & 10 & water & $0.97 \pm 0.01^{* * *}$ \\
\hline 43 & & Nov. & 10 & $30 \% \mathrm{EtOH}$ & $1.06 \pm 0.06^{* * *}$ \\
\hline 44 & & Nov. & 10 & $60 \% \mathrm{EtOH}$ & $1.09 \pm 0.01^{* \star *}$ \\
\hline 45 & & Nov. & 15 & water & $0.60 \pm 0.00^{* *}$ \\
\hline 46 & & Nov. & 15 & $30 \% \mathrm{EtOH}$ & $0.87 \pm 0.01^{* * *}$ \\
\hline
\end{tabular}

${ }^{11}$ Data are presented as the mean \pm SD. The dat were statistically evaluated using one-way analysis of variance (ANOVA) followed by Dunnett's Multiple Comparison test to compare significant differences between the groups (sprout, leaf, sprig and branch) at $\mathrm{p}<0.05,{ }^{* *} \mathrm{p}<0.01$ and ${ }^{* * *} \mathrm{p}<0.001$. 
적으로 낮은 수준의 quercetin 함량을 보이고 있으며 추출용 매의 차이도 크지 않는 것으로 측정되었다(p>0.05). Hyun 등(8)은 황칠나무 quercetin 함량을 성숙잎은 $0.0267 \mathrm{mg} / \mathrm{g}$ 으 로 보고하였으며 이는 재배환경, 추출방법 및 가수분해 유 무 등의 차이에 의한 것으로 생각된다.

이상의 분석결과, 10 년 이상 성숙한 황칠나무의 잎이 quercetin의 함량이 가장 높았으며 5 월에 채취하여 주정을 포함한 추출용매를 사용하면 가장 높은 quercetin함량을 갖 는 추출물을 제조할 수 있는 시기와 추출방법이라 사료된 다. 또한 본 연구결과를 활용하면 제품의 원료로 사용된 황칠나무로서 추출 부위, 수확시기 및 년생을 추적할 수 있는 품질관리 기준으로의 적용도 가능할 것으로 사료된 다.

\section{요 약}

본 연구에서는 quercetin 분석법의 유효성을 검증하고, 황칠나무의 부위, 수확시기 및 추출용매별quercetin 함량을 분석하였다. 분석결과의 신뢰도 확보를 위한 분석법 검증 에 대하여 특이성, 직선성, 정확성 및 정밀성을 확인하였으 며 그 결과, 표준용액의 피크유지시간과 spectrum이 황칠나 무 추출물과 일치하여 특이성을 확인 하였다. 검량선의 $\mathrm{R}^{2}$ 은 0.9996 으로 높은 직선성을 보였으며, 검출한계 $0.28 \mu$ $\mathrm{g} / \mathrm{mL}$, 정량한계는 $0.85 \mu \mathrm{\mu g} / \mathrm{mL}$ 였다. 회수율은 $98.37-$ $104.10 \%$ 의 범위로 나왔고, 일내분석과 일간분석에서 상대 표준편차는 각각 $2.11-3.65 \%$ 와 $1.36-2.98 \%$ 로 나왔다. 황칠 나무의 quercetin 함량은 $0.31-20.14 \mathrm{mg} / \mathrm{g}$ 의 범위로 가지보 다는 잎에서 높은 함량을 나타내었으며, 특히 10 년 이상 성숙하여 5 월에 채취된 잎의 경우 가장 높은 함량을 나타내 었다. 이처럼 황칠나무의 quercetin 함량은 부위, 수확시기 및 추출용매에 따라 함량 차이가 나타났으며, 기능성 식품 소재로서의 개발과 품질관리 기준 및 추후 제주산 황칠나무 연구의 기초자료로 활용이 가능할 것으로 사료된다.

\section{감사의 글}

본 연구는 (사)제주자원식물황칠사업단의 제주 황칠나 무의 원료표준화 및 기능성 연구개발사업에 의해 수행되었 으며 이에 감사드립니다.

\section{References}

1. Kim HK (2004) Current status and prospect of nutraceuticals. Food Industry and Nutrition, 9, 1-14
2. Choi U, Shin DH, Chang YS, Shin JI (1992) Screening of natural antioxidant from plant and their antioxidative effect. Korean J Food Sci Technol, 24, 142-148

3. KFDA (2007) Guideline for standard of health functional food. Korea Food and Drug Administration, Seoul, Korea, p 6-13

4. Jeong BS, Jo JS, Pyo BS, Hwang B (1995) Studies on the distribution of Dendropanax morbifera and component analysis of the golden lacquer. Korean J Biotechnol Bioeng, 10, 393-400

5. Choi SK (1996) Growth characteristcs and native environment of Dendropanax morbifera LEV. in Wando, Korea. Korean J Med Crop Sci, 4, 1-6

6. Lim KP, Jung WY (1998) Studies on the development of traditional Korean golden vamish (Hwangchil) (II) chemical composition and coating oil characteristics of the exudates and bark-extractives of Hwangchil namu (Dendropanax morbifera Lev.). Mokchae Konghak, 26, 7-13

7. Ahn JC, Kim MY, Kim OT, Kim KS, Kim SH, Kim SH, Hwang B (2002) Selection of the high yield capacity of Hwangchil lacquer and identification of aromatic components in essential oil of Dendropanax morbifera Lev.. Korean J Medicinal Crop Sci, 10, 126-131

8. Hyun TK, Ko YJ, Kim EH, Chung IM, Kim JS (2015) Anti-inflammatory activity and phenolic composition of Dendropanax morbifera leaf extracts. Ind Crops Prod, $74,263-270$

9. Chung IM, Kim MY, Park WH, Moon HI (2009) Antiatherogenic activity of Dendropanax morbifera essential oil in rats. Pharmazie, 64, 547-549

10. Moon HI (2011) Antidiabetic effects of dendropanoxide from leaves of Dendropanax morbifera Leveille in normal and streptozotocin-induced diabetic rats. Hum Exp Toxicol, 30, 870-875

11. Hyun TK, Kim MO, Lee H, Kim Y, Kim E, Kim JS (2013) Evaluation of anti-oxidant and anti-cancer properties of Dendropanax morbifera Leveille. Food Chem, 141, 1947-1955

12. Rice-Evans CA, Miller NJ, Bolwell PG, Bremley PM, Pridham JB (1995) The relative antioxidant activities of plant-derived polyphenolic flavonoids. Free Radical Res, 22, 375-383

13. Crozier A, Lean MEJ, McDonald MS, Black C (1997) Quantitative analysis of the flavonoid content of commercial tomatoes, onions, lettuce, and celery. J Agric Food Chem, 45, 590-595 
14. Ministry of Food and Drug Safety. http://www.mfds.go. $\mathrm{kr} /$ index $\cdot \mathrm{do} ? \mathrm{mid}=1162 \& \mathrm{seq}=5549 \& \mathrm{cmd}=\mathrm{v} \quad$ (accessed September 2012)

15. Ministry of Food and Drug Safety. http://www.mfds.go.kr /index.do?mid=1162\&seq=10382\&cmd=v (accessed December 2015)
16. Hu SJ, Oh JM, Oh HS, Moon MH, Bae YY, Lee SH, Kim JA, Koo YE (2016) Analysis of quercetin in extract of Hovenia dulcis Thunb. Anal Sci Technol, 29, 255-260

17. Wang H, Helliwell K (2001) Determination of flavonols in green and black tea leaves and green tea infusions by high-performance liquid chromatography. Food Res Int, 34, 223-227 